\author{
Abstracta Iranica \\ Abstracta Iranica Revue bibliographique pour le domaine irano-aryen \\ Volume 34-35-36 | 2017 \\ Comptes rendus des publications de 2011-2013
}

\title{
Kolsum Ghazanfari. Perceptions of Zoroastrian Realities in the Shahname. Zoroaster, Beliefs, Rituals
}

\section{Samra Azarnouche}

\section{(2) OpenEdition \\ Journals}

Édition électronique

URL : http://journals.openedition.org/abstractairanica/42774

DOI : 10.4000/abstractairanica.42774

ISSN : 1961-960X

Éditeur :

CNRS (UMR 7528 Mondes iraniens et indiens), Éditions de l'IFRI

Référence électronique

Samra Azarnouche, "Kolsum Ghazanfari. Perceptions of Zoroastrian Realities in the Shahname. Zoroaster, Beliefs, Rituals », Abstracta Iranica [En ligne], Volume 34-35-36 | 2017, document 3, mis en ligne le 30 juillet 2017, consulté le 01 octobre 2020. URL : http://journals.openedition.org/ abstractairanica/42774; DOI : https://doi.org/10.4000/abstractairanica.42774

Ce document a été généré automatiquement le 1 octobre 2020.

Tous droits réservés 


\title{
Kolsum Ghazanfari. Perceptions of Zoroastrian Realities in the Shahname. Zoroaster, Beliefs, Rituals
}

\author{
Samra Azarnouche
}

\section{RÉFÉRENCE}

Kolsum Ghazanfari. Perceptions of Zoroastrian Realities in the Shahname. Zoroaster, Beliefs, Rituals. Berlin, Logos Verlag, 2011, 271 p.

1 Issu d'une thèse soutenue à Göttingen, cet ouvrage analyse les représentations de la religion zoroastrienne dans le Shāhnāme et, partant, le problème de ses sources et du degré d'adaptation - ainsi que les procédés - opérée par le poète afin de ne pas heurter les sensibilités religieuses de ses contemporains. Le premier chapitre est une introduction sur le poète, ses sources et les mille vers emprunté à Daqīiī ; le second se consacre à Zarathushtra et la conversion de Goštāsp; le troisième aux «croyances zoroastriennes» (les dieux, les démons et la cosmogonie, la sorcellerie, les péris entités positives dans le Shāhnāme- , le farreh - traduit ici par " glory »-, la sagesse, l'eau, la joie, l'injustice, le mensonge, la triade éthique, la vengeance, la mort et l'au-delà); et le quatrième est dédié à la pratique rituelle (les ablutions, les āfrīnagān, le bāj et la barsom, dakhme et astōdān - synonymes dans le Shāhnāme -, le feu - notamment dans une fonction de qibla - , le kosti - le sedre n'étant pas attesté -, le mariage ; consanguin, les mobeds, les trois fêtes -Nōwrūz, Mehregān, Sadeh-, le serment et le contrat).

2 Sous un titre fort prometteur se déroule en réalité un catalogue des termes et des notions évoquant explicitement le culte iranien. Pour une raison inexpliquée, les motifs identifiables à un autre niveau de lecture sont laissés de côté. Parmi ceux-ci citons la structure narrative du Shāhnāme - sans doute son élément le plus «zoroastrien » - qui 
fait écho à la chronologie mythique déjà présente dans l'Avesta, ou les propriétés magiques des plumes du Sīmorgh qui rappellent celles de la plume du vāronjina (Yt 14.35-36), ou encore le motif du chevauchement du démon évoqué dans l'épisode où Siyāvaš s'approprie le cheval de son père qui rappelle Kərəsāspa monté sur le serpent (Yt 19.40) ou Tahmōrub dominant Ahreman selon les légendes parsies (MU 29).

3 Une critique de Mazdayasnā va adab-e fārsī (Téhéran, 1959), version corrigée et augmentée de la thèse de M. Mo'īn (1948) aurait également été bienvenue.

\section{AUTEURS}

\section{SAMRA AZARNOUCHE}

EPHE, Mondes iranien et indien 